\title{
Agency Theory Applied to the Italian Revenue Agency: Accountability Policies as Bonding Costs
}

\author{
Monia Castellini, Researcher, PhD \\ Vincenzo Riso
}

Department of Economics and Management, University of Ferrara, Ferrara

doi: 10.19044/esj.2016.v12n34p1 URL:http://dx.doi.org/10.19044/esj.2016.v12n34p1

\begin{abstract}
This paper aims at studying the consequences of the Agency Theory application at the case of the Italian Revenue Agency (afterwards IRA).

The major countries in the world entrust the tax administration to the Agencies that make use of various strategies to manage tax revenue and to contrast tax avoidance.

In the last years the Organisation for Economic Co-operation and Development (afterwards OECD) has invited many States to increase the tax compliance between Public Tax Administration and Taxpayers and to improve the relationship with these.

There are more scientific contributions about the themes like the Agency Theory, the Stakeholder's Theory and other more on Governance and Accountability policies: many of these will be discussed in this work.

In the light of these observations the research question is: given that IRA plays a central role in the tax administration, what happen if we apply the Agency Theory on this? What are the Agency costs in this case?

To answer to these question we have studied the Law provisions in the Italian tax field and the "way to do" of the IRA.

So, this work not is only a theoretical analysis of the scientific literature but it move to analyse the implications of these on the real case.

The conclusions achieved in this paper are based on the analysis of the Italian case that only partially brings a solution to this question.

However it represent the first point for us to beginning a future comparison between the evidences in the international context.
\end{abstract}

Keywords: New Public Management, Accountability, Agency Costs, Theory of Agency, Italian Revenue Agency 


\section{Introduction}

The international discussion about the relationship between the Public Administration and the Taxpayer is increased in sensitive way in the last years: many players, in the international context, have made their opinions and thoughts about this theme (OECD, 2013).

Maybe the most important, it is the search result made by the Organisation for Economic Co-operation and Development (afterwards OECD) exposed in the Paper "Tax Administration Comparative Information Series 2013” (Paris, 2013).

In this is underlined that it is very important, for Agencies in the different countries, to introduce in its operative actions "selected aspects of strategic management" and to focalize on the theme "human resource management and tax administration”.

It's not unusual that many Public governments use terms as "management" or "human resource management" within its administration.

Among the 1980, indeed, many public organizations have adopted the New Public Management's approach for which the governments leave its old way to manage and adopt this new way, new "vision”, to operate.

The term "New Public Management” it's utilized by C. Hood (1991) to explain the policy's target to modernize the public sector to make it into an organization more effective.

In this perspective, they are utilized logics typical for the private sector as "efficacy”, "efficiency" and others.

Therefore, in the public context, it was necessary to create a series of entities that have autonomy compared to the government and, for this reason, were born the Agencies: the clear aim was to separate the "political" perspective from the "operational” perspective.

Around this issue C. Hood asserts that the "focus on public service production functions and operational issues contrasted with the focus on public accountability, 'model employer' public service values, 'due process,' and what happens inside public organizations in conventional public administration” (C. Hood, 2001, p. 12556)

The New Public Management and its evolution, in fact, introduce within the Public Administration the "way to doing" used, historically, in the private companies. Unavoidably, were born a lot of implications about the "ownership structure" in the relationship between citizen and policy makers.

Implications about the Governance of these new organizations - it's important to underline that they are private organization that pursue a public interest - and its agency costs.

Indeed, towards a theoretical analysis of the different scientific literature we discover that the policies of accountability and transparency's actions represent a bonding cost for the Tax Authorities. 


\section{Methodological notes}

We consider the close relationships that exist in the scientific literature between some theories that up to now not be considered together.

This analysis in fact moves to put light the theoretical implications that arise if we consider at the same time these theories.

So, we think that often the major contribution brought by the scientific search is "to give name" to facts, situations, relations and a lot of things that before are unknown.

In this search, we analyse the following themes and theories (reported Tab.1) towards its major authors that had treated the matter:

Tab. 1: Analysis of literature

\begin{tabular}{|c|c|c|}
\hline THEMES CONSIDERED & CONSIDERATIONS & $\begin{array}{l}\text { PRINCIPAL AUTHORS } \\
\text { TREATED }\end{array}$ \\
\hline $\begin{array}{l}\text { New Public Management } \\
\text { and its evolution }\end{array}$ & $\begin{array}{l}\text { The evolution of Public } \\
\text { Administration and the } \\
\text { approach towards the citizen } \\
\text { have the central role in this } \\
\text { analysis and explain why } \\
\text { some tasks are entrusted to } \\
\text { the Agencies in the Public } \\
\text { context }\end{array}$ & $\begin{array}{l}\text { C. Hood (1995, 2001) } \\
\text { M. Haque (2009) } \\
\text { W.J. M. Kickert (2001) } \\
\text { A.G. Larbi (1999) } \\
\text { W. MC Court (2013) } \\
\text { A. G. Nhema (2015) } \\
\text { J.S.T. Quah (2013) } \\
\text { M. Robinson (2015) }\end{array}$ \\
\hline $\begin{array}{l}\text { The theory of the Agency } \\
\text { and the Agency costs }\end{array}$ & $\begin{array}{l}\text { The theory of the Agency } \\
\text { explain the dynamics of the } \\
\text { behaviour of the various } \\
\text { parties here considered }\end{array}$ & $\begin{array}{l}\text { M.C. Jensen }(1972,1983) \\
\text { W. Meckling }(1972) \\
\text { F.M. Fama }(1983) \\
\text { R. Freeman }(1988) \\
\end{array}$ \\
\hline $\begin{array}{l}\text { Accountability Policies and } \\
\text { Transparency’s Action in the } \\
\text { Public context }\end{array}$ & $\begin{array}{l}\text { The evolution of the Public } \\
\text { Administration's approach } \\
\text { towards citizens gave birth to } \\
\text { needs of accountability and } \\
\text { transparency's actions }\end{array}$ & $\begin{array}{l}\text { W. Norman (2004) } \\
\text { J. Heath (2004) } \\
\text { M. J. Ferris (1998) } \\
\text { A. E. Graddy (1998) } \\
\text { J. Amstrong (2001) } \\
\text { F. Biermann (2011) } \\
\text { A. Gupta (2011) }\end{array}$ \\
\hline $\begin{array}{l}\text { International Taxation Law, } \\
\text { Trust and Tax Compliance }\end{array}$ & $\begin{array}{l}\text { The implications by the } \\
\text { change of the approach in the } \\
\text { Public Administration have } \\
\text { consequences in the tax } \\
\text { law's field }\end{array}$ & $\begin{array}{c}\text { OECD (2010, 2013, 2014) } \\
\text { J. Stiglitz }(2012) \\
\text { J.I. Krueger }(2013) \\
\text { L.P. Feld }(2007) \\
\text { B.S. Frey (2007) }\end{array}$ \\
\hline
\end{tabular}

Source: Our elaboration

In this way we analyse the implications through the wide view of the themes treated here to demonstrate that the accountability and transparency's policies arise to contrast (or to improve) the "contractual nature" of the relationship between Tax Authority and Taxpayer. 


\section{The implications apported in the puclic context by the new public management and its evolution}

Many in the scientific literature that studied management and organization affirm that their theories are applicable indifferently to both public and private sectors (Kickert, 2001).

This is one of the issues for which in the 1980s was born the New Public Management Theory.

Indeed, the historical partition between private and public entities it was exceeded with the advent of the hybrid organization like agencies, public companies and other (Will 1975,Blair 1995,Perri and Kreamer 1985).

On this theme Kickert asserts, "In recent decades, the importance of an intermediate realm has been greatly increased by the retreat of the welfare state. Many Western (Europe) governments have moved away from direct delivery of a variety of public services. They have privatized or otherwise divested them-selves of these functions, in some cases transforming the agencies that performed them into hybrid organizations. These organizations are expected to function like businesses: to be efficient, customer driven, and client oriented. Yet, they perform tasks that are inherently public. In other words, they are supposed to act as if they were situated in the private sphere, while at the same time remain within the public sphere” (Kickert, 2001, p. 136).

Appear clearly the features of this new approach that many States have provided in their law system: efficacy, efficient and customer oriented (Larbi, 1999).

An important question is: what are the needs for which was theorized this new approach?

There are many theories on this but the most conventional explains that the combination of the crisis on one hand and the neo-liberal ideas, on the other, pushed to implementation of change's politics.

These affirmations are supported by the thoughts of Larbi that says: "NPM reforms have been driven by a combination of economic, social, political and technological factors. A common feature of countries going down the NPM route has been the experience of economic and fiscal crises, which triggered the quest for efficiency and for ways to cut the cost of delivering public services. The crisis of the welfare state led to questions about the role and institutional character of the state” (Larbi, 1999, p. 4).

The change in new forms of organization and the different way to think the relationship with citizens are fundamental elements in the transaction "old-new” form of management.

The citizen take place a central role in the strategies of the many Countries, not only the OECD countries but also those in developing (Mc Court, 2013, Morse, 1992, Harvey, 2009). 
However, it is very important to underline "a discrepancy between the trust of public sector reform efforts in developing country contexts and wider shifts in the nature of governance and contemporary approaches to public management grounded in OECD experience”. (Robinson M., 2015 p. 4).

To understand this evolution of different approaches about the management of the Public Administration is good take shape summarily this simple path: from Old Public Administration (since 1970s) to New Public Management (since 1980s) and to New Public Management to New Public Service. This path had its roots into the Max Weber's thought: in fact, in his conception of administration, based principally on the bureaucratic model, Weber thinks six principals features (Nhema, 2015):

- $\quad$ Hierarchy of authority according to which: the system of organization was oriented in a strong "top-down" way;

- Division of labour: is important, in this conception, cut division of labour to employ specialised experts in each specific position;

- Impersonality: the consideration about the political choices must be without personal consideration;

- Technical qualification: it is favoured the technical qualification against arbitrary dismissal;

- Procedural specification: in this perspective is fundamental the explication and codification of the rules

- Continuity: anyone who wants to pursue a career within the organization can do it.

So, these features have influenced strongly the path of evolution in the Public Administration way to manage and to organize its activities.

The Old Public Administration, in 1970s, emphasizes some features of the Weberian Model (McCourt 2013, Minogue 2001): it was a system centralized, controlled in the hierarchical way and thought with rules and guidelines that provided the largely of the actions within the organization.

In this perspective "public servants serve public rather than private interest” (Robinson M., 2015).

After the Old Public Administration, called also "command and control" model, it has come to the New Public Management in 1980s.

It was emerged specially in OECD countries, as already mentioned before, after then increasing as reaction to the inability of the Old Public Administration to respond to the citizen needs in the same way efficacy and efficiency which has the market (Hood, 2001)

The switch between the different approaches is here: in the sensibility of the promoters of the New Public Management to achieve the presence of the citizen's needs in its strategies. 
They're many empiric evidences about the political success into the countries where the New Public Management had taken place: for example, the Singapore's model, that it's unique of a kind (Quah, 2013).

Singapore is the singular case where there is a close relationship between citizen and politics, relationship founded on mutual trust: in according to the prevailing literature, this situation is difficult to repeat.

In particular, this model of organization is characterized by these features (Quah, 2013):

- $\quad$ Reform of the Singapore Civil Service;

- $\quad$ Strong and enforceable anticorruption measures;

- $\quad$ Decentralization of the Public Service Commission;

- $\quad$ Payment of competitive market salaries to attract and retain the candidates in the public service.

Is very interest, about this, the words of Haque that says: "Another concern emerging from these current changes in governance based of organizational disaggregation (e.g. autonomous agencies), use of multiple stakeholders (private, non-government, and foreign), and expansion of budget autonomy, is the potential barrier to the realization of public accountability due to the growing difficulty to coordinate, manage, and monitor these new structures and institutional arrangements. In this regard, the optimistic aspects of the Singapore case are its highly capable state to steer the situation and its relatively small public sector (due to small population) that is more easily manageable" (Hacque, 2009, p. 13).

The New Public Management evolves in the New Public Service (some researchers have considerate also an intermediate phase called New Public Governance) (Robinson, 2015).

The concept that "the public role of servants is to help citizens" is the key of interpretation of this approach.

Furthermore, in this there isn't the self-interest of public management.

The figure of citizen is change: this isn't a client or a customer where the relationship is configured in a top-down way (McCourt 2013, Hood 1995). In fact, theory of democracy and participation of citizens to the public administration are new imperatives in this vision: the relationship is configured as bottom-up (Greenawalt, 2016, Cropf, 2016).

There are more implications derived by an approach configured in this way: the role of the citizen in a bottom-up organization provides the possibility to re-think the way to participate of these in the public life.

The policy maker include the citizen interest in the process of decision making, plan the strategic view in according to its needs. 
Therefore, in this last perspective, there is surely discretion of the government actions but driven by the constrictions derived by the monitoring's citizen control.

This path is excellently summary by McCourt (2013) in the Tab. 2.

There are surely more considerations about these observations: at first is useful, for research purposes, observe that in the Public Management's evolution the citizen has changed its role within the layout of State's structure.

\begin{tabular}{|c|c|c|c|}
\hline & Problem & Approach & $\begin{array}{c}\text { Main action } \\
\text { period }\end{array}$ \\
\hline 1 & $\begin{array}{l}\text { How can we put government on } \\
\text { an orderly efficient footing? }\end{array}$ & $\begin{array}{l}\text { "Weberian" public } \\
\text { administration and } \\
\text { capacity-building }\end{array}$ & $\begin{array}{c}\text { Post - } \\
\text { independence }\end{array}$ \\
\hline 2 & $\begin{array}{l}\text { How can we get government } \\
\text { closer to the grassroots? }\end{array}$ & Decentralization & 1970s to present \\
\hline 3 & $\begin{array}{c}\text { How can we make government } \\
\text { more affordable? }\end{array}$ & $\begin{array}{l}\text { Pay and employment } \\
\text { reform }\end{array}$ & 1980s and 1990s \\
\hline 4 & $\begin{array}{c}\text { How can we make government } \\
\text { perform better and deliver on } \\
\text { our key objectives? }\end{array}$ & New Public Management & 1990s to present \\
\hline 5 & $\begin{array}{l}\text { How can we make government } \\
\text { more honest? }\end{array}$ & $\begin{array}{l}\text { Integrity and anti- } \\
\text { corruption reforms }\end{array}$ & 1990s to present \\
\hline 6 & $\begin{array}{l}\text { How can we make government } \\
\text { more responsive to citizens? }\end{array}$ & “Bottom-up” reforms & $\begin{array}{c}\text { Late } 1990 \text { s to } \\
\text { present }\end{array}$ \\
\hline
\end{tabular}

Tab. 2.: The evolution of the Public Administration approach in according to McCourt (2013): public service reform problems and approaches Source: Elaboration reported in M. Robinson (2015) p. 5

The empowerment of citizen, its participation in the public life and its involvement in the public interest decision are the guidelines that move the new "way to do" in the good Public Administration (McCourt, 2013).

Furthermore, another important observation: it's obvious that this evolution take place in different way in each country, in according to the historical features of these.

It's empirical evidence, the challenges that the globalization and the open markets have led are hard and submit not little difficulties (Abony and Van Slyke, 2010).

The new technologies have the capacity to orientate the actions of the government to create alternative form of participation.

In fact, in according to the principles of transparency and the public access, the new technologies provides the opportunity to "bringing citizen closer to police making process through new and improved channel of participation as well as citizen monitoring of government" (Avila, Feigenblatt, Heacock, Heller, 2011, p. 4). 
In the second paragraph of this work we analyse the influence of this new approach within the tax field in Italy in according to the conclusions reached by the application of the M.C. Jensen and W. Meckling's "theory of principal-agent” to IRA.

Summary, to close this part, it's important understand the path's evolution of the logics in which the citizen it was thought (Denhardt and Denhard, 2000):

- $\quad$ as a client and constituent in the Old Public Administration based on the Political theory;

- $\quad$ as a customer in the New Public Management based on the Economic and Positivist theory;

- $\quad$ as a citizen in the New Public Service based on Democratic theory.

Surley, we agree with Gyong J.E. that affirms: "Good governance no doubt is absolutely necessary for the achievement of social political and economic progress in any society. It is the means through which the State can effectively address the allocation and management of resources to enable it respond to the collective good of society without discrimination. Failure to give country good governance can result to widespread corruption and abuse of due process. The results are lack of accountability and widespread poverty of the vast majority, thus making them vulnerable to easy manipulation and exploitation by the elite” (Gyong J.E., 2014, p. 88).

\section{Agency theory and agency costs to italian revenue agency}

Maybe the most important scientific contribution in the field is the article published by M.C. Jensen and W. Meckling in 1976: "Theory of the Firm: Managerial Behaviour, Agency Cost and Ownership structure”.

In according to the Authors, there is a close relationship between the ownership structure and the behaviour of the Managers or of the Owners.

Yet in the first part of their script, they assert that the "analysis casts new light on and has implications for a variety of issues in the professional and popular literature including the definition of the firm, the "separation of ownership and control," the "social responsibility" of business, the definition of a "corporate objective function," the determination of an optimal capital structure, the specification of the content of credit agreements, the theory of organizations, and the supply side of the completeness of markets problems” (Jensen and Meckling, 1976, p. 2).

Now, for what concerns here, is important underline the essence of this theory: the model "Principal-Agent" and the theory of the Agency costs.

The Authors define the relationship between the Principal and the Agent as "a contract under which one or more persons (the principal(s)) engage another person (the agent) to perform some service on their behalf 
which involves delegating some decision making authority to the agent" (Jensen and Meckling, 1976, p. 6).

From this idea derives a series of consequence sentences: for example, what happens if both parties, Principal and Agent, maximize their interests and their utilities?

Exist a clear "interest conflict" because, affirm the Authors, "there is a good reason to believe that the Agent will not always act in the best interest of principal” (Jensen and Meckling, 1976, p. 6).

Furthermore, surely there are different ways to limit this contrast as incentives granted by the Principal to Agent with the aim to restrict unseemly actions for it.

In the light of this assumption, appear clearly that to smooth the divergences born by the interest conflict, arise some costs held by Principal and Agent.

Therefore the Authors (Jensen and Meckling, 1976) theorized the presence of three major types of costs emerged by this interaction:

- $\quad$ the monitoring expenditures by the Principal;

- $\quad$ the bonding expenditures by the Agent;

- $\quad$ the residual loss.

There are, then, others phenomena as the Hazard Moral and the Adverse Selective every time that the Agent has more information compared to the Principal and has the opportunity to use this Asymmetry Information to procure itself an advantage.

Now, after the focus placed on the Agency costs, we analyse the implications derived by the ownership structure in relation with Agency costs.

There is a correlation between the number of owners and their influence on the Agent: the structure of the ownership determines the capacity of the Principal to control the Agent.

The empirical evidence shows that in the companies where there are a lot of shareholders there are higher Agency costs rather then where there are few shareholders (Scarpa, 2009).

So, for this reason, the Agency costs increase where there is a wide separation between ownership and control.

The conclusions of the M.C. Jensen and W. Meckling's script affect, surely, also the Public Administration that in the last years have adopted the New Public Management or New Public Service approaches.

For what concerns this work, in the light of the search reasons exposed in the abstract, it's possible to apply the model "Principal-Agent" to the Italian Revenue Agency.

The first issue is to understand: who is the Principal in the paradigm Principal-Agent here? 
In according to the previous definitions, established that the Italian Revenue Agency is the Agent, exist two perspectives, internal and external, that define two different Principal.

On one hand, in internal perspective, there is the Minister of Economics and Finance and, on the other hand, in external perspective, there is the taxpayer and, in general, the citizen.

In the Public sector, in fact, it's possible to have "multiple principals" because the Agent has some relationship between different interlocutors (Ferris, Graddy, 1988).

The Authors assert: "A perplexing dimension of public sector applications of principal agent theory is the existence of multiple principals. Moe (1984) has suggested that government is a serial set of principal agent relationships with citizens as ultimate principal (e.g., citizens and their representatives; representatives and the executive branch; and superiorsubordinate relationship within the bureaucracy)" (Ferris and Graddy, 1988, p. 6).

So, here we consider only two principal relationships: in the next paragraph we will show, brief, the internal perspective and then, in analytical way, the external perspective.

In the external perspective - in according with what reported in the previous paragraph - we show how the policies of accountability required by New Public Management approach represent bonding expenditures in the paradigm Principal-Agent.

\section{Internal perspective: principal as minister of economics and finance}

As shows in Figure 3., there are two typical Agency costs deriving by the relationship between the Minister of Economics and Finance and the Italian Revenue Agency: the Monitoring Expenditures for the first and the Bonding Expenditures for the second.

The Italian Revenue Agency enjoys its own autonomy and operates with their goals to manage the tax system and to contrast the tax avoidance.

So, the best way to reach the goals, in the logics of the New Public Management, is operate in according to the forms of organizations that allow achieving the best result.

Therefore, the Minister needs to receive a series of information to understand if the behaviour of this Agent (IRA) was been correct.

Thus, this information is not only utilized to create performance indicators but it has the task of demonstrating the quality of his operations.

So, in respect of the recommendations by OECD, the Italian Government provides a set of indicators that shows how the Italian Revenue Agency should increase the Tax Revenue not only counteracting tax 
avoidance but also amplifying the Tax Compliance and the spontaneous fulfilment.
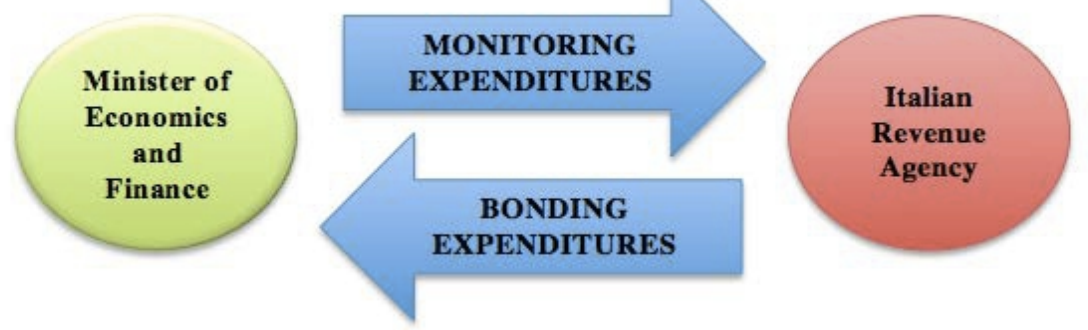

Figure 3: Minister of Economics and Finance and Italian Revenue Agency in the Theory of Agency's perspective

Source: Our elaboration

In the last years, in fact, the major countries in the world, focalizes its attention on the right of the taxpayer: why?

In their famous research paper the OECD explains the difference between "Enhanced Relationship concept" and "Co-operative compliance", affirming that need to pass from the first to the second.

The OECD affirms: "When in 2008 the Study into the Role of Tax Intermediaries defined the collaborative, trust-based relationship based on the pillars listed above, the name "enhanced relationship" was chosen as a term that properly distinguished this approach from an obligation-based basic relationship. (...) The term "enhanced relationship" has also raised questions about the nature of the approach and may have given rise to connotations of inequality in tax treatment. In short, large corporate taxpayers and revenue bodies, while they are satisfied that the principles on which the approach is based remain sound, are concerned that the name "enhanced relationship" has given rise to misunderstandings and in some cases suspicion that the concept violates important principles, such as equality before the law". (OECD, 2013, p. 14):

Maybe the answer to the question "why the Tax Intermediaries use methods to operate with connotations of inequality in tax treatment?" is: the various intermediaries, Agencies or similar, have great autonomy to manage the tax system.

Furthermore, when there is defined clearly the goal but not the principles to achieve it, is possible that the Agent distorts the way to achieve its goal and misunderstands the aim of its actions.

In this perspective, therefore, takes a fundamental role the Principal's actions of control, (in this case the Italian Minister of Economics and 
Finance) that mustn't only control the fairness and correctness of the operations of the IRA but must address it towards a fair way to achieve its goals.

In few words, is fundamental that the Minister sets clearly the "strategic and political view".

As an example, to understand if the IRA increase the Tax Revenue deriving higher Tax Compliance, the Italian Government provides a series of indicators in the law D. Lgs. 157/2015 and specify in the Agreement between the IRA and Minister of the Economics and Finance 2015-2017 (Provided by the article 59, part 2, 3 and 4 of the D. Lgs. 30/1999), reported in Tab. 4:

Tab. 4: Set of KPI's provided by Minister of Economics and Finance to control the Italian Revenue Agency

\begin{tabular}{|c|c|}
\hline $\begin{array}{l}\text { GOALS AND } \\
\text { KPIs }\end{array}$ & Other disclosures \\
\hline \multicolumn{2}{|c|}{ Goal: Simplify the fulfilments and improve the quality of the offered services } \\
\hline \multirow{5}{*}{ KPI 1} & Indicator of Customer Satisfaction \\
\hline & Signed agreements for dispensing services \\
\hline & Number of telephone responses offered by CAM or by small call centre \\
\hline & Number of responses in written form (as sms, web-mail) \\
\hline & $\begin{array}{l}\text { Actual detail data referred to the indicators that make up the "Barometer of the } \\
\text { service's quality", "Percentage of the cadastral update acts and avoided } \\
\text { cartographic" and "Percentage of the real estate advertising upgrade finished" }\end{array}$ \\
\hline \multirow{5}{*}{ KPI 2} & $\begin{array}{l}\text { Number of tax declaration "Unico PF" transmitted the channel "Fiscoonline" / } \\
\text { Total Number of tax declaration "Unico PF" }\end{array}$ \\
\hline & Number of tax declaration "Unico PF" transmitted by the taxpayer \\
\hline & $\begin{array}{l}\text { Number of communications sent by 31/12/2015 compared to the tax declarations } \\
\text { "Unico 2013" received }\end{array}$ \\
\hline & $\begin{array}{l}\text { Number of communications sent by 31/12/2015 compared to the tax declarations } \\
\text { "Unico 2014" received }\end{array}$ \\
\hline & Percentage of the communication of irregularity annulled \\
\hline KPI 3 & $\begin{array}{c}\text { Number of acts of practises (circular and resolution) and operative instructions } \\
\text { provided in relation to the interpretation activity of tax law }\end{array}$ \\
\hline
\end{tabular}

Source: Our adaptation by Italian version reported in the Agreement between the IRA and Minister of the Economics and Finance 2015-2017, pg. 10 of enclosure 4.

In this Box there are three principal KPIs referred to the strategic area of services.

Every KPI dishes out to understand "the quality" of the relationship between IRA and Taxpayers.

Trough a comparison between these indicators and the evidence of increasing or decreasing of Tax Revenue will be possible understand if the major revenue deriving by a better compliance or not.

Surely, in the paradigm Principal-Agent, to gather these information and to elaborate means more Agency costs (or transitions costs), so like asserts by Ferris and Graddy: "Thus, such arrangements, which are often pursued for efficiency gains (reduced production costs) may require 
significant transaction costs in order to ensure public accountability)” (Ferris and Graddy, 1988, p. 2).

It is unavoidable and these costs represent an investment to have higher performance in the future (Jensen and Meckling, 1976).

To endorse this thought are lighting these words: "The dilemma for the national governments is how to develop fiscal strategies that reduce the ability of lower-level governments to thwarts its goals, taking into account its own objectives, the information requirements (i.e. transactions costs), and subnational governance capacity. Two key strategies are subsidies (e.g. intergovernmental grants) and regulations (e.g. funded mandates). The informational needs, and thus transactions costs, required to implement these strategies differ" (Ferris and Graddy, 1988, p. 8).

In the light of this assumptions, it's possible analyse the second perspective, here said "external", where to role of Principal is assigned to the Citizen.

\section{External perspective: principal as citizen or taxpayer}

In the Figure 5 it's possible observe the structure of the relationship between the Citizens and the IRA.

The number of Principals, in this case, is very wide: as explained in the first part of this work, when the number of principals is high the Agency costs increase and the capacity of the Principals to smooth the asymmetry information is very low (Meier and Bohte, 2003). Every citizen (or taxpayer) has no much bargaining power (only the little red arrow in the figure) while the IRA has the possibility to implement mechanism of communication whereby demonstrate "the quality" of its operations.

Figure 5: Citizen (or Taxpayer) and Italian Revenue Agency in the Theory of Agency's perspective

Source: Our elaboration

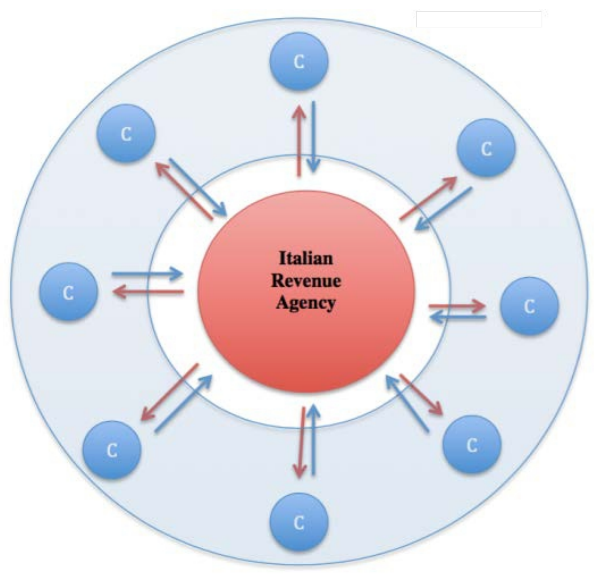


It's clear that, here, the Agents (every single agent of the IRA) have the opportunity to benefit exploiting the asymmetry information: the risk of the corruption's phenomena is obvious.

Just now takes more sense the thoughts of Rahaman, Liberman, Giedraitis and Akhter: "NPM system contrasted with the focus on public accountability, 'model employer' public service values, 'due process,' and what happens inside public organizations in conventional public administration” (Rahaman, Liberman, Giedraitis and Akhter, 2013, p. 298).

So, to smooth these divergences the OECD explains that every tax intermediaries must change their "way to doing" for which there aren't different treatment towards taxpayers and citizens in general (OECD, 2013).

Why it's fundamental this change? Why, in this particular period of history, OECD and the major countries focalize its attention on tax compliance?

In the last years, after the events post financial crisis, the citizens have lost the truth in the governments and, more in general, in the government system.

J. Stiglitz (2012) explains that the financial crisis had generated a deep distrust of institutions (private and public) and this fact will lead to a global recession.

To avoid the mistrust the companies and the public governments have incorporated in its strategy more importance to the external communication and, in particular, towards the stakeholders (Castellini, 2007).

There are a lot of contributions on the "Stakeholder Theory" (Phillips et al, 2003) as "theory as organization management and ethics" for which the company or the Agency, in this case, must have the knowledge of every interest of their stakeholders and inserts this information within its strategy.

There is, maybe, an "advanced” form of accountability where the aim is not only to "account" what was done but it's to involve the stakeholders in the definition of the strategic plan.

There is a close relationship between "Stakeholder Theory" and "New Public Service" and both theories had influenced hardly the actual management of Public Administration and Private Companies.

\section{Accountability policies of ira as bonding costs}

Why the "Accountability" policies represents, in the external perspective, the bonding costs for the IRA?

The OECD asserts "People are generally comfortable with being accountable for things they can control" (OECD, 2014, p. 30) and this is the start point to explain because the "accountability policies" represent bonding costs. 
In the definition of the bonding cost we understand that it's incurred by the Agent to assurance the Principal on the "quality" of its actions (that the behaviour of Agent is coherent with the expectations of Principal) (Jensen and Meckling, 1976).

For this reason, across the accountability policies the IRA has the opportunity to show their results to citizen in according with the New Public Service approach.

In this sense the provisions of the law D. Lgs. 157/2015, yet treated before, represent the clear aim of the government to put the citizen in the decision-making-process.

Now, it's fundamental clarify what means “accountability”.

We agree with the thought of Biermann and Gupta that affirm: "In essence, accountability has four elements: (1) a normative element, that is, a standard of behaviour defined with sufficient precision; (2) a relational element, linking those who are held accountable to those who have the right to hold to account; (3) a decision element, that is, a judgment of those actors who may hold other actors accountable about whether the expected standard of behaviour has been met; and finally (4) a behavioural element that allows the governing actor to sanction deviant behaviour of those held accountable. All elements need to be present in sufficient degree to make any accountability relationship meaningful". (Biermann and Gupta, 2011, p. 1857) affirm that:

Relating this assumption at the case here analysed, it's possible - $\quad$ Normative element: there are a series of the provisions like the OECD guidelines, the European Union Recommendations and finally, in Italy surely the most important in this case, the Law D. Lgs. 157/2015 and the set of performance indicators provided by the Agreement between the IRA and Minister of the Economics and Finance 2015-2017.

It's important specify that these are only provisions in tax field but there are others Public Administration's reforms that move in this sense (here not treated);

- $\quad$ The relation element: it is represented by the link between IRA and taxpayer, where the taxpayer have the opportunity to control the actions of IRA;

- The decision element: the capacity of the IRA to increase the tax compliance, improved actions that including the taxpayer in its decisionmaking process;

- The behavioural element: this is represented by the level of tax avoidance because the incapacity of the IRA to increase the tax compliance or to contrast tax avoidance with control system leads the taxpayer to do this behaviour. 
In the light of these assumptions, it's possible qualify the strategy of IRA to increase the tax compliance like a politics of accountability and transparency's actions.

Indeed, the management of tax system in Italy is undergoing sensitive change, driven by the guidelines of OECD and the tax strategies of the principal world's Economics.

So, clarified this point, it's important to underline that these bonding costs represent surely a relevant investment in term of resources (scarce for definition) but it is necessary to achieve the objectives yet described.

Indeed, this investment (a real cost) is the key to beginning a process of change and to increase the tax compliance and the spontaneous fulfilment.

The OECD, in its publication of 2014s, focuses its attention on the theme of accountability, as reported in the following Figure 6.

In the paper "Measurement of Tax Compliance Outcomes - A Practical Guide" (OECD, 2014, p. 81) it is explained the TADAT (Tax Administration Assessment Tool) that "provides an objective and standardised performance assessment of a country's system of tax administration".

Figure 6: Performance Outcomes Area in according to the Tax Administration Assessment Tool

Source: Elaboration of T.A.D.A.T.

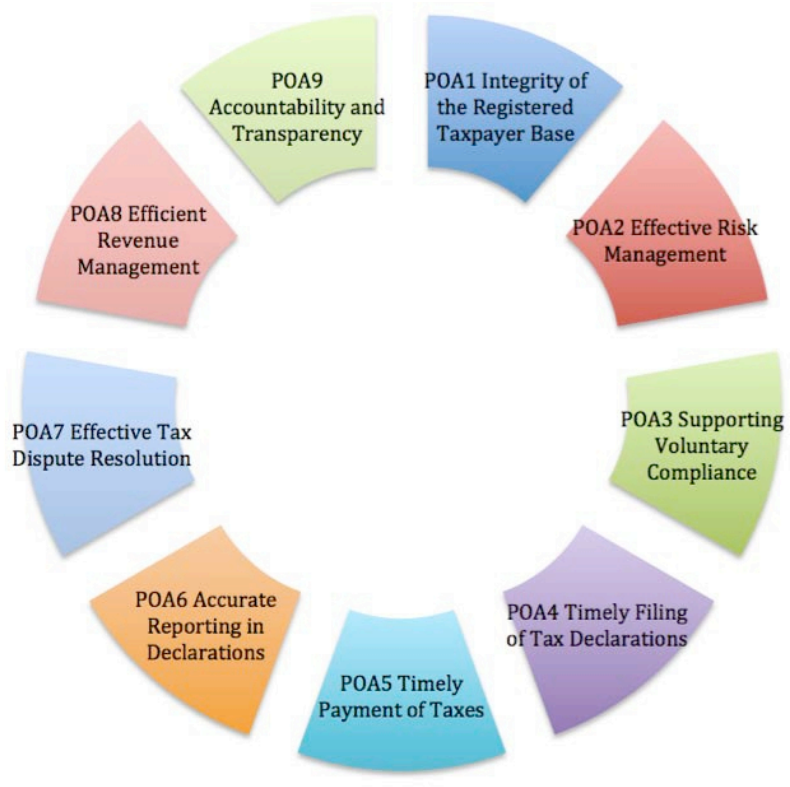

This tool represents an instrument for an international community and it is supported by European Commission, Germany, Japan, Netherland, Norway, Switzerland, United Kingdom and the World Bank (through the International Monetary Fund and its Secretariat). 
In the Table 7 we report the set of indicators provided in the area “Accountability and Transparency”.

To conclude this part of work, it's important to focus our attention on the communication's strategies incurred by IRA.

Tab. 7: KPIs on the Transparency and Accountability's actions in according to the Tax Administration Assessment Tool

\begin{tabular}{|c|c|}
\hline P9 - 25 Internal assurance mechanisms & $\begin{array}{l}\text {-Assurance provided by internal audit } \\
\text {-Staff integrity assurance mechanism }\end{array}$ \\
\hline $\begin{array}{l}\text { P9 - 26 External oversight of the tax } \\
\text { administration }\end{array}$ & $\begin{array}{l}\text {-The extent of independent external oversight } \\
\text { of the tax administration's operations and } \\
\text { financial performance } \\
\text {-The investigation process for suspected } \\
\text { wrongdoing and maladministration }\end{array}$ \\
\hline P9 - 27 Public perception of integrity & $\begin{array}{l}\text {-The mechanism of monitoring public } \\
\text { confidence in the tax administration }\end{array}$ \\
\hline $\begin{array}{c}\text { P9 - } 28 \text { Publication of activities, results, } \\
\text { and plans }\end{array}$ & $\begin{array}{l}\text {-The extent to which the financial and } \\
\text { operational performance of the tax } \\
\text { administration is made public, and the } \\
\text { timeliness of publication } \\
\text {-The extent to which the tax administration's } \\
\text { future directions and plans are made public, } \\
\text { and the timeliness of publication }\end{array}$ \\
\hline
\end{tabular}

Source: Elaboration of T.A.D.A.T.

It's relevant the communication's strategies in the external perspective because across these the Citizen have the opportunity to understand the new approach of the IRA and have the possibility to change its behaviour, increasing the tax compliance.

Indeed, the external communication is a strong opportunity for the IRA to orientate the perception of the taxpayer towards a principle of equality and parity.

\section{Conclusion}

The analysis conducted in this work shows in that way it's possible apply the theory of the paradigm Principal-Agent to the Italian Revenue Agency and explains the existence of two perspectives (in the concept of the "multiple principals"): internal and external.

There is a close relationship between these two perspectives:

- In the internal, the Principal is the Minister of Economics and Finance that has a wide span of control compared to the IRA.

It is very important to define clearly the Strategy Plan whereby it will be possible to smooth the divergences deriving by the asymmetry information. 
We think that in the planning phase it's desirable that participate together and in closely both Top managements (Minister and IRA) to understand in which way set up the Strategic Plan, defining objectives and performance to achieve these.

- In the external, the Principal is the Citizen that has a low span of control compared to the IRA.

In order to implement the key recommendations of the OCED and increase the tax compliance, it's really fundamental beginning with a strong politics of accountability where the citizens are in the centre of the objectives.

The politics of accountability represent a crucial investment and have the central role in the IRA's Strategic view.

The Agency Theory shows as it's impossible to the IRA remove this cost but at the same time, this bonding cost and the accountability's politics represent a grate opportunity of change.

The joint vision of these perspectives gives the opportunity to orientate the behaviours of IRA towards a better way to do, increasing the spontaneous fulfilment by taxpayers.

Furthermore, to confirm this, there is a wide international scientific literature (Freeman, 1984; Mitchell et al, 1997; Donaldson, Preston, 1999) that studied the importance of the stakeholder in the strategic planning and had theorized the Stakeholder Theory.

More contributes focalized its attention to:

- $\quad$ Define and classify the different types of Stakeholders;

- $\quad$ Demonstrate the ethic's role rather then strategic recognized to the Stakeholders;

- Identify the way whereby the Stakeholders legitimate own operations.

In the tax field, in the opinion of the writers, is relevant to take a particular focus on the last point.

Indeed, is essential understand the needs of the citizens and taxpayers and plan (in the strategic way) the actions to satisfy these needs.

The OECD identifies, in its work, the features that can help the Agencies to implement mechanism of "co-operative compliance": "Changing from a "traditional" control approach to a co-operative compliance approach in many cases is the result of the development of a compliance risk management strategy. The rationale for relationships of this kind is to create a joint approach to improving tax risk management and overall tax compliance, with benefits for both parties. In response to the survey almost all countries responded that the co-operative compliance model with large corporate taxpayers is part of a wider (compliance) strategy". The overall conclusion is that co-operative compliance models are 
firmly rooted in the overall (compliance) strategy of the revenue body" (OECD, 2013, p. 28).

The taxpayers have expressed their needs of disclosure and transparency and they see the "co-operative compliance" as "Transparency in exchange for certainty".

To observe the needs of taxpayer, citizen or a stakeholder in general is useful to introduce an analysis of customer satisfaction (Ugolini Baldassari, 2010).

We endorse the words of Temizel M.: "It has been admitted that the relationship between state and society has changed from a control and hierarchy mecanism into a network governance where the society as a whole share decision making process in some way. The governance reform has been described as set of values such as; accountability, transparency, participation and foreseeability which meet citizens' expectations and requirements and help the state to increase good performance displaying capacity" (Itemize M., 2015, p. 224).

In conclusion, we believe that in this a particular period of the history characterized by uncertainly and lack legitimacy, the best strategy for the IRA is smooth the divergences born by the contractual relationships and increase its legitimation following a political of accountability in according to a new strategy (utilizing the stakeholder's approach).

The policies of accountability and the transparency's actions represent, in according to the contractual relationship between the parties, a bonding costs: this not be eliminated but at the same time represent an opportunity to achieve the change.

The application of these reflections and its empirical evidences are left to others future studies or to anyone with an interest in this theme.

\section{References:}

1. ABONYI G., D.M. VAN SLYKE (2010) Governing on the Edge: Globalization of Production and the Challenge to Public Administration in the Twenty-First Centaury, Public Administration Review. Special Issue on the Future Public Administration in 2020. Vol. 70

2. AMSTRONG J. (2001) Executive Agencies \& Good Governance, The Governance Network, Discussion Paper,

3. A VILA R., FEIGENBLA TT H., HEACOCK R., HELLER N. (2001) Global Mapping of Technology for Transparency and Accountability, London: Transparency and Accountability initiative, Mimeo 
4. BIERMANN F., GUPTA A., 2011 Accountability and legitimacy in earth system governance: A research framework, Ecological Economics, pp. 1856 - 1864

5. CASTELLINI M. (2007) Il ruolo degli Stakeholder per l'efficacia degli obiettivi strategici nelle aziende pubbliche. Il caso dell'Agenzia Spaziale Italiana - Azienda Pubblica, Vol. 1, pp: 141-162

6. CASTELLINI M. (2007) La gestione strategica delle aziende pubbliche: il ruolo della comunicazione esterna, Forum Editrice, vol.2, pp.129-148

7. CHRISTENSEN T., LAEGREID P. (2011) Complexity and Hybrid Public Administration - Theoretical and Empirical Challenges, Public Organization Review, vol. 9, n. 4, pp. 407 - 423

8. CLARKSON M. (2001) “A Stakeholder Framework for Analyzing and valuating Corporate Social Performance”, Academy Management Review, vol. 20, n. 1

9. COASE, R. H. (1960) “The Problem of Social Cost.”, Journal of Law and Economics III pp. 1-44

10. CORE P., (1993), “Accountability in the public sector”, in Australian public service:pathways to change in the 1990s, Edited by J. Guthrie, North Sydney: IRR Conferences Pty, Ltd, pp. 48-53.

11. CROPF R.A., T.C. BAGWELL (2016) Ethical Issues and Citizen Rights in the Era of Digital Government Surveillance, IGI Global

12. DILL W., (1975), Public participation in corporate planning: Strategic Management in a kibitzer's world, Long Range Palnning, 8(1): pp. 57-63.

13. DENHARDT R.B., DENHARDT J.V. (2000) The New Public Service: Serving rather than Steering, Public Administration Review, vol. 60, n. 6, pp. $549-559$

14. EVAN W.M., FREEMAN R.E. (1988) "A stakeholder theory of the modern corporation: Kantian capitalism”, in Beauchamp T. \& Bowie (Ed.), Ethical theory in business, Englewood cliffs, Prentice Hall, pp. 75-93

15. FAMA F.E., JENSEN M.C. (1983) Agency Problems and Residual Claims, Journal of Law and Economics, vol. 26

16. FELD L.P., FREY B.S. (2008) Tax Compliance as the Result of a Psychological Tax Contract: iș îThe Role of Incentives and Responsive Regulation, LAW \& POLICY, Vol. 29, n.1

17. FERRIS M. JAMES, GRADDY A. ELIZABETH (1998) A contractual framework for New Public Management Theory, International Public Management Journal, pp. 225-240

18. GYONG J.E. (2014) Good governance and accountability in a democracy, European Scientific Journal, Vol. 7, n. 26, pp. 71-89 
19. GRAY A., JENKINS W. (1993) "Codes of accountability in the new public sector", Accounting Auditing and Accountability Journal, vol. 6, n. 3, pp. 52-67.

20. GREENAWALT K. (2016) From the Bottom Up: Selected Essays, Oxford University Press

21. GRUENING G. (2001) Origin and theoretical basis of New Public Management, International Public Management Journal, vol. 4, pp. 125

22. HAQUE M. (2009) Public Administration and Public Governance in Singapore, In Pan Suk Kim, ed., Public Administration and Public Governance in ASEAN Member Countries and Korea. Seoul: Daeyoung Moonhwasa Publishing Company, pp.246-271

23. HARVEY P. (2009) Towards good humanitarian government - The role of the affected state in disaster response, Humanitarian Policy Group

24. HEATH J., NORMAN W., (2004) Stakeholder Theory, Corporate Governance and Public Management: What can the History of StateRun Enterprises Teach us in the Post-Enron era?, Journal of Business Ethics 53: 247-265

25. HYKAJ K. (2016) Corporate Governance, Institutional Ownership, and Their Effects on Financial Performance, European Scientific Journal, vol. 12, n.25, pp. 46-69

26. HOOD C. (2001) New Public Management - International Encyclopaedia of the Social and Behavioural Sciences, 18, Amsterdam, New York, pp. 12553-56

27. HOOD C. (1995) The "NEW PUBLIC MANAGEMENT" in the 1980s:

28. Variations on the theme, Accounting, Organizations and Society, Vol. 2, n.2/3, pp. 93-109,

29. JENSEN M.C., MEKLING W. (1972) Theory of the firm: Managerial behaviour, agency costs and ownership structure, Journal of Financial Economics

30. KICKERT W. J. M. (2001) Public Management of hybrid organizations: governance of quasi-autonomous executive agencies, International Public Management Journal, 4, pg. 135-150

31. KRUEGER J. I., EVAN A. M. (2013) Fiducia - Il Dilemma Sociale Essenziale, In-Mind Italia, istepij

32. ITALIAN REVENUE AGENCY, Agreement between the IRA and Minister of the Economics and Finance 2015-2017, Provided by the article 59, part 2, 3 and 4 of the D. Lgs. 30/1999

33. LARBI A. G. (1999) The New Public Management approach and Crises States, UNRISD Discossuion Parper n. 112 
34. MC COURT W. (2013) Models of Public Service reform: A Problem-Solving Approach, Policy Research Working Paper, n. 6428, Washington D.C., The World Bank

35. MEIER K.J. (2003) Span of Control and Public Organizations: Implementing Luther Gulick=s Research Design, Public Administration Review, Vol. 63, No. 1, pp. 61-70

36. MORSE. S.W. (1992) Public Leadership Education: The Role of Citizen Leaders, Charles K. Kettering Foundation

37. NHEMA A. G. (2015) Relevance of Classical Management Theories to Modern Public Administration: A Review, Journal of Public Administration and Governance, vol. 5, n. 3, pp. $164-173$

38. OECD (2010) Value for Money in Government, Public Administration after "New public Management

39. OECD (2013) CO-OPERATIVE COMPLIANCE: A FRAMEWORK - From Enanched Relationship to co-operative compliance

40. OECD (2014) Measures of Tax Compliance Outcomes - A Practical Guide

41. PAVAN A. (2012) REGINATO E., PROGRAMMAZIONE E CONTROLLO NELLE AMMINISTRAZIONI PUBBLICHE. Gestione per obiettivi e contabilità integrata., GIUFFRÉ

42. QUAH J.S.T. (2013) Ensuring Good Governance in Singapore: is the experience transferable to other Asian Countries?, International Journal of Public Sector Management, vol. 26, n. 5, pp. $401-420$

43. RAHMAN MD. M., L.S. LIBERMAN, V.R. GIEDRAITIS, T. AKHTER, (2013) The Paradigm from Traditional Public Administration to New Public Management System in Bangladesh: What Do Reform Initiatives Stand for?, Advances in Economics and Business, pp. 297-303

44. RICCARDO MUSSARI (2002) Il Controllo di Gestione nell'Amministrazione Finanziaria dello Stato - L'esperienza dell'Agenzia delle Entrate, Rubettino

45. ROBINSON M. (2015) From Old Public Administration to the New Public Service, Implication for Public Sector, Reform in Developing Countries, Global Centre For Public Service Excellence

46. ROBINSON M. (2007) The Politics of Successful Governance Reform: Lessons of design and implementation, Commonwealth and Comparative Politics, vol. 45, n. 4 , pp. 521 - 548

47. ROLANDO S. (2012) La comunicazione pubblica per un'identità solidale: nuovi equilibri di responsabilità sociale tra Pubbliche Amministrazioni e cittadini in GENTILE A., GIANNINI S., EVASIONE FISCALE E “TAX COMPLIANCE”, Il Mulino 
48. SCARPA D., Un'analisi economica del diritto: teoria dell'agenzia e rapporto di amministrazione, downloaded on ALTALEX at 26.10.2016

49. STEWART J. D. (1984) "The Role of Information in Public Accountability”, in Hopwood A., Tomkins C. (a cura di), Issues in Public Sector Accounting, Phillip Allan Publishers Limited, London, pp. 13-34.

50. STIGLITZ J. (2012) The price of inequality, Norton \& Company

51. TEMIZEL M. (2015) Transformation of public administration and the approach of governance, European Scientific Journal, Special Edition, pp. 216-227

52. UGOLINI G., BALDASSARI S. (2011) L'impiego della Customer Satisfaction per la valutazione dell'efficacia esterna nelle attività delle pubbliche amministrazioni in ISTAT 